\title{
KARAKTERISTIK FISIKOKIMIA TEPUNG KACANG TURI BERBUNGA PUTIH (Sesbania grandiflora) DENGAN BEBERAPA PERLAKUAN PENDAHULUAN
}

\section{PHYSICOCHEMICAL CHARACTERISTIC OF FLOUR MADE FROM WHITE FLOWERING TURI SEED (Sesbania grandiflora) USING VARIOUS PRETREATMENT}

\author{
Dwi Ishartani $^{1)}$, Dian Rachmawanti Affandi ${ }^{1)}$, Dessy Cahya Purnamasari ${ }^{2)}$ \\ 1) Staff JurusanTeknologi Hasil Pertanian, Fakultas Pertanian, Universitas Sebelas Maret Surakarta \\ 2) Alumni Program Studi Teknologi Hasil Pertanian, Fakultas Pertanian, Universitas Sebelas Maret Surakarta
}

Email: distani@yahoo.com

\begin{abstract}
This research aimed to study the effect of pretreatment on chemical (ash, lipid, protein, phytic acid, cyanide acid) and physical properties of flour made from white flowering turi seed. The research used Completely Randomized Design with one factor that was pretreatment. Samples being observed were control (F1), 90 minutes boiling with testa (F2), 24 hours soaking with testa (F3), tersta dehulling (F4), 90 minutes boiling with tersta dehulling (F5), and 24 hours soaking with tersta dehulling (F6). The result showed that all pretreatment lowering ash, phytic acid, and cyanide acid content compare to control. Testa dehulling, either not combined (F4) or combined with 90 minutes boiling (F5) and combined with 24 hours soaking (F6) resulted flour contain higher lipid and protein compare to control. Both combined with testa dehulling or not combined, 90 minutes boiling and 24 hours soaking $((F 2, F 3, F 5, F 6)$ resulted lower lipid and protein content compared to control. Turi seed flour contain highest lipid and protein was the one that pretreated with testa dehulling (F4) while contain least lipid and protein was the one that pretreated with 90 minutes boiling without testa dehulling (F2). Phytic acid and cyanide acid were most reduced in sample pretreated by 90 minutes boiling with tersta dehulling (F5) whether least reduced in sample pretreated by tersta dehulling (F4). Generally pretreatment decreased bulk density and solubility of the flour produced, except flour pretreated with 90 minutes boiling without testa dehulling (F2) that not different compared to control. Whiteness degree of the flours produced were vary, the most white was pretreated by tersta dehulling (F4) and the least white was preatreated by 90 minutes boiling without testa dehulling (F2).
\end{abstract}

Keywords : boiling, soaking, chemical properties, testa dehulling, white flowering turi seed flour

\section{ABSTRAK}

Tujuan penelitian ini adalah mempelajari pengaruh perlakuan pendahuluan terhadap sifat kimia (abu, lemak, protein, asam fitat, dan asam sianida) serta sifat fisik (derajat putih, densitas kamba, dan kelarutan) tepung kacang turi berbunga putih. Penelitian ini menggunakan rancangan acak lengkap dengan satu faktor, yaitu perlakuan pendahuluan yang meliputi: kontrol (F1), perebusan 90 menit dengan kulit (F2), perendaman 24 jam dengan kulit (F3), pengupasan kulit (F4), perebusan 90 menit kupas kulit (F5) dan perendaman 24 jam kupas kulit (F6). Hasil penelitian menunjukkan bahwa seluruh perlakuan pendahuluan menghasilkan tepung dengan kadar abu, asam fitat dan asam sianida $(\mathrm{HCN})$ yang lebih rendah dibandingkan kontrol. Perlakuan pendahuluan pengupasan baik dengan maupun tanpa perebusan 90 menit dan perendaman 24 jam (F4, F5, F6) menghasilkan tepung dengan kadar lemak dan kadar protein lebih tinggi dibandingkan kontrol. Perebusan 90 menit dan perendaman 24 jam menghasilkan tepung dengan kadar lemak dan protein lebih rendah dibandingkan kotrol baik yang dikupas maupun yang tidak dikupas kulitnya (F2, F3, F5, F6). Tepung dengan kadar lemak dan protein tertinggi yaitu tepung dengan perlakuan pendahuluan pengupasan kulit (F4) dan tepung dengan kadar lemak dan protein terendah yaitu tepung dengan perlakuan pendahuluan perendaman 24 jam tanpa pengupasan kulit (F2). Penurunan kadar asam fitat dan asam sianida terbesar terjadi pada perlakuan pendahuluan perebusan 90 menit disertai pengupasan kulit (F5) sedangkan yang terkecil pada perlakuan pendahuluan pengupasan kulit (F4). Secara umum, perlakuan pendahuluan menurunkan densitas kamba dan kelarutan tepung yang dihasilkan, kecuali tepung dengan perlakuan pendahuluan 24 jam tanpa pengupasan kulit (F2) yang memiliki densitas kamba yang tidak berbeda nyata dengan kontrol. Derajat putih tepung dengan berbagai perlakuan pendahuluan cukup variatif, yang paling tinggi derajat putihnya adalah tepung dengan perlakuan pendahuluan pengupasan kulit (F4) dan yang paling rendah adalah tepung dengan perlakuan pendahuluan perendaman 24 jam tanpa pengupasan kulit (F2).

Kata kunci : pengupasan kulit, perebusan, perendaman, sifat kimia, tepung kacang turi berbunga putih 


\section{PENDAHULUAN}

Turi (Sesbania grandiflora) merupakan salah satu jenis kacang-kacangan yang sudah banyak dikenal di seluruh nusantara, terutama untuk wilayah Indonesia bagian tengah dan timur. Produktivitas turi di Indonesia kirakira 20 ton/ha/tahun (data pada tahun 1979)(Sutikno,1999).Kacang turi memiliki 2 varietas, yaitu kacang turi berbunga putih dan berbunga merah (Agus, 2001). Berdasarkan Devi (2011) komposisi kimia kacang turi yaitu kadar air $10,14 \%$, lemak $7,10 \%$, protein $36,21 \%$, dan serat kasar 12,64\%. Meskipun komposisi gizi kacang turi cukup lengkap, pemanfaatan kacang turi sebagai ingredient pangan belum banyak dilakukan. Halini dikarenakan tekstur kacang turi cukup keras dan kemungkinan tingginya senyawa anti gizi.

Senyawa anti gizi adalah suatu senyawa yang terdapat dalam beberapa bahan pangan yang dapat menghambat penyerapan zat gizidalam tubuh. Menurut Astawan (2009) beberapa jenis kacang-kacangan mengandung senyawa anti gizi yaitu asam sianida $(\mathrm{HCN})$ dan asam fitat. HCN dalam kacang turi berbunga putih dapat diketahui dari rasa pahit. Jika dicerna, HCN sangat cepat terserap oleh alat pencernaan masuk ke dalam saluran darah dan terikat bersama oksigen. Bahaya HCN terutama pada sistem pernafasan, dimana oksigen dalam darah terikat oleh $\mathrm{HCN}$ dan terganggunya sistem pernafasan. Sedangkan asam fitat akan membentuk ikatan kompleks dengan zat besi atau mineral lainsepertiseng,magnesium, dan kalsiummenjadi bentuk yang tidak larut dan sulit diserap tubuh. Oleh sebab itu, perlu dilakukan perlakuan pendahuluan untuk mengurangi senyawa anti gizi pada kacang turi. Beberapa penelitian menunjukkan bahwa proses perendaman, perebusan, dan pengupasan kulit dapat mengurangi kandungan senyawa antigizi yang ada dalam tanaman-tanaman leguminosae (El-Adawy, 1999; Mohammed et al., 2011).

Pada penelitian ini kacang turi berbunga putih yang banyak tumbuh di daerah Klaten akan diolahmenjadi tepung dengan pemberian perlakuan pendahuluan berupa pengupasan, perebusan 90 menit, dan perendaman 24 jam. Teknologi penepungan merupakan salah satu proses alternatif produk setengah jadi yang dianjurkan untuk mempertahankan umur simpan bahan, mudah dicampur dengan tepung lain (untuk dibuat komposit), diperkaya zat gizi (difortifikasi), dibentuk, dan lebih cepat dimasak sesuai tuntutan kehidupan modern yang ingin serba praktis (Widowati, 2009). Perlakuan pendahuluan tersebut selain diharapkan dapat menurunkan senyawa asam fitat dan $\mathrm{HCN}$, juga dapat mempengaruhi kandungan gizi dan sifat fisiktepung yang dihasilkan.Oleh karena itu dalam penelitian ini akan diamati pengaruh perlakuan pendahuluan berupa perebusan 90 menit tanpa pengupasan kulit, perendaman 24 jam tanpa pengupasan kulit, pengupasan kulit, perebusan 90 menit dengan pengupasan kulit, danperendaman 24 jam dengan pengupasan kulitterhadap sifat fisik dan kimia tepung kacang turi berbunga putih.

\section{METODE PENELITIAN}

\section{Bahan dan Alat}

Bahan yang digunakan dalam penelitian ini adalah kacang turi berbunga putih yang diperoleh dari sekitar Klaten. Bahan-bahan yang digunakan untuk analisa adalah $\mathrm{HCl}$, $\mathrm{K}_{2} \mathrm{SO}_{4}, \mathrm{HgO}, \mathrm{H}_{2} \mathrm{SO}_{4}, \mathrm{H}_{2} \mathrm{BO}_{3}$, methylene red, methylene blue, heksana, aquades.

Alat-alat yang digunakan dalam pembuatan tepung kacang turi antara lainmesin penyosohdan mesin blender. Alat yang digunakan untuk analisasifat kimia dan fisik adalah neraca analitik, oven, tanur, desikator,seperangkat alat destruksi, destilasi, dan titrasi Kjeldahl, seperangkat alat ekstraksi soxhlet, colorimeter,pompa vakum,dan peralatan gelas.

\section{Tahapan Penelitian}

\section{Penepungan kacang turi berbunga putih}

Penepungan kacang turi berbunga putih dalam penelitian ini mengacu metodeEkawati (1999) yang dimodifikasi oleh Pangastuti (2012). Biji kacang turi mula-mula dibersihkan dari kotoran, dipilih yang ukurannya seragam, tidak keriput, dan utuh (tidak berlubang). Selanjutnya kacang turi diberi perlakuan pendahuluan, meliputi kontrol (F1), perebusan 90 menit dengan kulit $(\mathrm{F} 2)$, perendaman 24 jam dengan kulit (F3), pengupasan kulit (F4), perebusan 90 menit 
kupas kulit (F5) dan perendaman 24 jam kupas kulit (F6). Kacang turi kemudian dicuci, dioven sampai kadar air 6-6.5\%, digiling, dan diayak 80 mesh hingga didapatkan tepung kacang turi berbunga putih.

\section{Analisis sifat fisikokimia}

Analisis kadar abu, lemak, dan protein mengikuti metode AOAC (1999), analisis asam fitat mengikuti Wheeler dan Ferrel (1971), analisis HCN mengikuti AOAC (1975), derajat putih mengikuti AnguloBejarano et al. (2008) dalamHarnani (2009), densitas kamba mengikuti Pinasthi (2011), dan kelarutan mengikuti Apriyantono dkk (1989) dalam Adriani (1997).

\section{HASIL DAN PEMBAHASAN}

Hasil analisis sifat kimia dan sifat fisik tepung kacang koro berbunga putih dapat dilihat pada Tabel 1.

\section{Kadar Abu}

Hasil analisis terhadap kadar abu pada tepung kacang turi berbunga putihdilihat pada Tabel 1. Perlakuan pendahuluan secara umum menghasilkan tepung kacang turi berbunga putih dengan kadar abu yang lebih rendah. Kadar abu yang lebih rendah terutama disebabkan oleh proses perebusan 90 menit dan perendaman 24 jam, baik yang dikupas kulitnya (F5 dan F6) maupun yang tidak (F2 dan F3). Perlakuan perebusan 90 menit dan perendaman 24 jam diduga melarutkan mineral kacang turi berbunga putih. Menurut deMan (1989) dalam Padmawinata (1997), proses perendaman dapat menyebabkan larutnya mineral. Namun, perlakuan pengupasan kulit tidak mempengaruhikadar abu tepung kacang turi berbunga putih yang dihasilkan. Mineral kacang turi berbunga putih diduga lebih banyak terdapat pada kotiledon, sehingga pengupasan kulit tidak mempengaruhi kadarabu pada tepung yang diberi perlakuan pendahuluan pengupasan kulit. Hal ini serupa pada penelitian pada kacang hijau yang telah dilakukan oleh Mubarak (2005) bahwa pada kacang hijau kupas kulit mempunyai kadar abu sebesar 3,60\% dan pada kulit kadar abu hanya sebesar $0,16 \%$.

\section{Kadar Lemak}

Nilai kadar lemak pada tepung kacang turi berbunga putih disajikan pada Tabel 1 . Perlakuan berupa perebusan 90 menitbaik dengan kulit maupun kupas kulit menghasilkan tepung dengankadar lemak yang lebih rendah dibanding tepung kontrol. Hal ini diduga karena proses perebusan 90 menit menyebabkan penetrasi air panas dalam bahan lebih baik sehingga lemak lebih mudah terhidrolisis dan hasil hidrolisisnya terdispersi dalam air rebusan. Perlakuan perendaman selama 24 jam menyebabkan penurunan kadar lemak yang lebih kecil dibandingkan dengan perebusan selama 90 menit. Penurunan kadar lemak kacangkacangan selama perendaman juga ditemukan pada perendaman moth bean (Mankotia dan Modgil, 2003). Audu dan Aremu (2011) mengemukakan bahwa penyebab penurunan lemak selama perendaman dan perebusan adalah karena adanya lemak yang terdispersi pada air perendaman dan air rebusan.Pangastuti (2012) menambahkan, perendaman dapat mengaktifkan enzim lipase yang dapat menghasilkan beberapa asam lemak bebas rantai pendek yang mudah terdispersike dalam air media perendaman.

Tepung dengan perlakuan pendahuluan pengupasan kulitsecara umum menghasilkan tepung dengan kadar lemak lebih tinggi dibandingkan tepung tanpa perlakuan pendahuluan pengupasan kulit. Hal ini ditunjukkan dari presentase kadar lemak tepung kacang turi berbunga putih kupas kulit baik pada tanpa kombinasi perlakuan (F4), dengan kombinasi perebusan 90 menit (F5), dan dengan kombinasi perendaman 24 jam (F6) yang lebih tinggi dibandingkan dengan tepung kacang turi berbunga putih dengan kulit baik pada tanpa kombinasi perlakuan (control=F1), dengan kombinasi perebusan 90 menit (F2), dan dengan kombinasi perendaman 24 jam (F3). Hal ini diduga karena lemak lebih banyak terdapat pada kotiledon dibandingkan pada kulit, sehingga dengan adanya pengupasan kulit berpengaruh pada jumlah presentase kadar lemak yang lebih tinggi. Hasil penelitian ini serupa dengan penelitian Marquardt et al. (1975) bahwa koro babi mempunyai kadar lemak 
Tabel 1. Sifat Kimia dan Sifat Fisik Tepung Koro Berbunga Putih dengan Berbagai Perlakuan Pendahuluan

\begin{tabular}{lrrrrrr}
\hline \multicolumn{1}{c}{ Sifat Kimia/ } & \multicolumn{5}{c}{ Perlakuan Pendahuluan } \\
\cline { 2 - 7 } & \multicolumn{1}{c}{ F1 } & F2 & F3 & F4 & F5 & F6 \\
& (kontrol) & & & & & \\
\hline As. Fitat (mg/kg) & $2145.4^{\mathrm{f}}$ & $454.29^{\mathrm{c}}$ & $863.35^{\mathrm{d}}$ & $1557.71^{\mathrm{e}}$ & $56.26^{\mathrm{a}}$ & $270.14^{\mathrm{b}}$ \\
HCN (mg/kg) & $39.69^{\mathrm{c}}$ & $14.50^{\mathrm{ab}}$ & $22.45^{\mathrm{b}}$ & $20.52^{\mathrm{b}}$ & $6.85^{\mathrm{a}}$ & $14.55^{\mathrm{ab}}$ \\
Abu (\%) & $4.02^{\mathrm{d}}$ & $2.37^{\mathrm{bc}}$ & $2.68^{\mathrm{c}}$ & $3.92^{\mathrm{d}}$ & $2.25^{\mathrm{bc}}$ & $1.44^{\mathrm{a}}$ \\
Lemak (\%) & $9.91^{\mathrm{b}}$ & $9.64^{\mathrm{a}}$ & $9.76^{\mathrm{ab}}$ & $10.93^{\mathrm{d}}$ & $10.57^{\mathrm{c}}$ & $10.74^{\mathrm{c}}$ \\
Protein (\%) & $14.69^{\mathrm{c}}$ & $13.47^{\mathrm{a}}$ & $13.87^{\mathrm{b}}$ & $17.35^{\mathrm{e}}$ & $15.84^{\mathrm{d}}$ & $15.95^{\mathrm{d}}$ \\
Derajat putih (\%) & $70.25^{\mathrm{b}}$ & $65.09^{\mathrm{a}}$ & $70.64^{\mathrm{b}}$ & $76.26^{\mathrm{c}}$ & $72.58^{\mathrm{c}}$ & $71.60^{\mathrm{b}}$ \\
Densitas kamba (g/cm $\left.{ }^{3}\right)$ & $0.48^{\mathrm{d}}$ & $0.50^{\mathrm{d}}$ & $0.46^{\mathrm{c}}$ & $0.40^{\mathrm{b}}$ & $0.43^{\mathrm{b}}$ & $0.38^{\mathrm{a}}$ \\
Kelarutan (\%) & $38.57^{\mathrm{d}}$ & $18.79^{\mathrm{a}}$ & $30.16^{\mathrm{bc}}$ & $35.08^{\mathrm{cd}}$ & $14.16^{\mathrm{a}}$ & $27.34^{\mathrm{bc}}$ \\
\hline
\end{tabular}

pada kotiledon (sebesar 1,1\%)lebih tinggi dibandingkan pada kulit (sebesar 0,3\%).

\section{Kadar Protein}

Dari Tabel 1 terlihat bahwa perlakuan pendahuluan dan kombinasinya mempengaruhi kadar protein tepung yang dihasilkan secara signifikan. Perebusan 90 menit dan perendaman 24 jammenghasilkan tepung dengankadar protein lebih rendah dibandingkan dengan tepung yang tidak diberi perlakuan perebusan dan perendaman baik yang dikombinasikan dengan pengupasan kulit maupun yang tidak dikupas kulitnya. Pola yang sama dilaporkan juga oleh Nzewi dan Egbuonu (2011), yaitu perebusan menurunkan kandungan protein pada asparagus bean, sertaCahyo (2012) pada perebusan dan perendaman biji saga. Penurunan kandungan protein tersebut disebabkan karena difusi substansi nitrogen yang larut ke dalam air rendaman dan air rebusan Cahyo (2012). Menurut Veen dan Schaefer (1950), selama proses penghilangan kulit, perendaman dan perebusan terjadi pengurangan nitrogen sebesar 3,9-8,0\% pada kacang-kacangan, sedangkan menurut Nurhidayat dkk. (2006) selama perendaman protein kacang kedelai total turun sebesar 1,4\%. Perendaman 24 jam menghasilkan tepung dengan kadar protein lebih tinggi dibandingkan dengan perebusan 90 menit pada kombinasi perlakuan yang sama, yaitukadar protein sampel F3 lebih tinggi daripada sampel F1 dan F2 (tanpa kombinasi pengupasan kulit), serta kadar protein sampel F6 sama dan lebih tinggi daripada sampel F5 dan F4 (dengan kombinasi pengupasan kulit) - Selama proses perebusan 90 menit diduga terjadi penetrasi air panas dalam bahan lebih baik dan karena suhu tinggi menyebabkan meningkatnya energi kinetik bahan dan menyebabkan molekul penyusun protein bergerak cepat sehingga merusak ikatan molekul protein, sehingga banyak $\mathrm{N}$ yang terdispersi dalam media perebusan (Coimbra dan Jorge, 2011).

Pengupasan kulit mempengaruhi kandungan protein tepung kacang turi berbunga putih yang dihasilkan. Hal ini ditunjukkan dari kadar protein pada tepung kacang turi berbunga putih kupas kulit lebih tinggi dibandingkan dengan kulit. Dengan demikian dapat dikatakan bahwa kadar protein kotiledon kacang turi berbunga putih lebih tinggi dibandingkan dengan kulitnya.Penelitian Alonso et al. (2000) dalam Ejigui et al. (2005) menunjukkan adanya peningkatan kandungan protein sebesar6\% pada kacang merah setelah pengupasan kulit, dan penelitian Marquardt et al. (1975) menunjukkan kadar protein kotiledon koro babi yang lebih tinggi (sebesar $36,3 \%$ )dibandingkan dengan kulitnya(sebesar $5,9 \%)$.

\section{Kadar Asam Fitat}

Kadar asam fitat tepung kacang turi berbunga putih ditunjukkan pada Tabel 1 . Hasil ini menunjukkan bahwa perlakuan perendaman 24 jam mampu menghasilkan tepung dengan kadar asam fitat yang lebih rendah dibandingkan dengan tepung tanpa perlakuan pendahuluan perendaman atau perebusan (F1 dan $\mathrm{F} 4)$. Larutnya asam fitat 
akibat perendaman ini terjadi karena asam fitat pada kacang-kacangan pada umumnya terdapat dalam bentuk garam larut air yang diduga merupakan kalium fitat (Crean dan Haisman, 1963 dalam Khattab dan Arntfield, 2009).Menurut Konietzny and Greiner (2006), kadar asam fitat dapat diturunkan selama perendaman,hal ini disebabkan karena terlarutnya asam fitat pada air rendaman.Selain itu, perendaman juga dapat menyebabkan meningkatnya aktivitas enzim fitase yang merupakan salah satu enzim yang dapat menghidrolisis asam fitat menjadi inositol dan orthofosfat sehingga mampu mengurangi kandungan asam fitat (Setyono, 1987 dalam Sutardi dan Hartuti, 1993).

Kadar asam fitat pada tepung dengan perlakuan perebusan 90 menit mempunyai kadar yang paling rendah dibandingkan dengan perlakuan lain. Berdasarkan hasil penelitian Mohamed et al.; (2011) diketahui perebusan kacang merah selama 90 menit dapat mereduksi asam fitat sebesar 19,1\%. Adanya reduksi dalam pemasakan ini disebabkan karena ion-ion fitat yang melepaskan diri ke dalam media pemasakan. Hal tersebut didukung dengan Pangastuti (2012) menyatakan bahwa proses terlarutnya fitat dalam air rebusan disebabkan oleh reaksi yang terjadi antara $\mathrm{Na}$ fitat yang terdapat di dalam daging biji dengan $\mathrm{Ca}$ atau $\mathrm{Mg}$ pektat yang tidak larut yang terdapat di dalam dinding sel, khususnya di dalam kulit biji membentuk Na pektat yang larut.

Dalam penelitian ini didapat hasil bahwa kadar asam fitat tepung dengan perlakuan pendahuluan pengupasan kulit lebih rendah dibandingkan dengan tepung yang tidak dikupas kulitnya. Hal ini diduga bahwa dalam kacang turi berbunga putih, kadar asam fitat juga banyak terdapat pada kulit. Menurut Paramita (2008), asam fitat pada kacang-kacangan banyak terdapat pada kulit bijinya. Oleh karena itu, dengan adanya pengupasan kulit, mampu mengurangi asam fitat pada tepung kacang turi putih secara signifikan.Penurunan kadar asam fitat dengan adanya perlakuan pengupasan kulit serupa dengan hasil penelitian Mubarak (2005), yaitu pada kacang hijau dengan kulit mempunyai kadar asam fitat sebesar 5,80 $\mathrm{mg}$ /gram dan setelah dikupas kadar asam fitat menjadi lebih rendah yaitu sebesar 4,60 $\mathrm{mg} / \mathrm{gram}$.

\section{Kadar HCN}

Senyawa hidrogen sianida dalam jumlah tertentu dapat menyebabkan kematian. Dosis yang mematikan yaitu sekitar 0,5-3,5 mg HCN/kg berat badan.

Perlakuan pendahuluan pada penelitian ini secara umum menurunkankadar $\mathrm{HCN}$ tepung kacang turi berbunga putih yang dihasilkan secara signifikan. Winarno (2004) yang mengungkapkan bahwapengolahan ubi kayu pahit dengan perlakuan pengeringan dan perendaman sebelum dimasak dapat menurunkan kadar HCN hingga menjadi 10 sampai $40 \mathrm{mg} / \mathrm{kg}$. Penelitian Bourdoux et al.; (1982) jugamenunjukkan tren yang serupa, yaitu penurunankadar $\mathrm{HCN}$ sebesar $45 \%$ pada perlakuan perendaman satu hari. Menurut Winarno (2004), HCN mempunyai sifat mudah larut dalam air sehingga dengan adanya perendamanan 24 jam mampu menurunkan kadar HCN secara signifikan.

\section{Derajat Putih}

Derajat putih merupakan salah satu faktor penentu kualitas dari tepung-tepungan. Produk tepung-tepungan biasanya diharapkan memiliki derajat putih yang tinggi. Tabel 1 menunjukkan nilai derajat putihtepung kacang turi berbunga putih dari tertinggi sampai terendah, yaitu tepung dengan perlakuan pendahuluan pengupasan kulit $(\mathrm{F} 4)$ $(76,26 \%)$; tepung dengan perlakuan pendahuluan kupas kulit dan perebusan 90 menit (F5) (72,58\%); tepung dengan perlakuan pendahuluan kupas kulit dan perendaman 24 jam (F6) (71,60\%); tepung dengan perlakuan pendahuluan perendaman 24 jam tanpa kupas kulit (F3) (70,64\%); tepung control (F1) $(70,25 \%)$; dan tepung dengan perlakuan pendahuluan perebusan 90 menit tanpa pengupasan (F2) $(65,09 \%)$.

Warna kulit pada kacang-kacangan ditentukan oleh jumlah senyawa fenolik yang dikandungnya, yaitu flavonol glikosida, antosianin, dan tanin (Feenstra, 1960 dalam Anton et al.; 2008). Senyawa fenolik ini merupakan antioksidan yang baik. Tanin mempunyai warna putih-kuning sampai coklat muda dan bila terkena sinar matahari akan teroksidasi menjadi coklat tua 
(Hilyatuzzahroh, 2006). Sehinggawarna coklat pada kacang-kacangan dapat menandakan tingginya kandungan tanin. Kacang turi putih mempunyai warna kulit coklat muda sampai coklat tua, sedangkan pada biji kotiledon kacang turi mempunyai warna kuning kecoklatan. Menurut Apriyantoro (2009), kacang-kacangan memiliki warna coklat dari pigmen dan akan berpengaruh terhadap warna produk jika kacang-kacangan tersebut ditambahkan pada bahan lain.

Hasil penelitian ini menunjukkan perlakuan perebusan 90 menit tanpa pengupasan kulit (F2) menghasilkan tepung dengan derajat putih yang paling rendah. Hal ini diduga disebabkan oleh proses ekstraksi tannin ke dalam air perebus sekaligus oksidasi tannin selama perebusan yang ditandai dengan perubahan warna air perebus dan kacang menjadi coklat agak kemerahan. Tannin mempunyai sifat larut air dan dapat teroksidasi jika mendapat cahaya dan dibiarkan pada tempat yang terbuka (Siregar, 2009). Selain itu, pencoklatan pada bahan diduga juga disebabkan oleh reaksi oksidasi yang dikatalisis oleh enzim fenol oksidase atau polifenol oksidase pada kacang, terutama pada perlakuan pendahuluan yang dikombinasikan dengan perendaman. Menurut Mardiah (1996), kedua enzim ini dapat mengkatalis oksidasi senyawa fenol menjadi quinon dan kemudian dipolimerasi menjadi pigmen melaniadin yang berwarna coklat; sehingga berpengaruh pada derajat putih tepung menjadi lebih rendah.

Hasil penelitian ini juga menunjukkan bahwa perlakuan pendahuluan yang dikombinasikan dengan pengupasan kulit menghasilkan tepung dengan derajat putih yang lebih tinggi jika dibandingkan dengan perlakuan pendahuluan yang tidak dikombinasikan dengan pengupasan kulit . Hal ini diduga karena kulit kacang turi berbunga putih yang berwarna coklat mengandung senyawa tannin dan senyawa polifenol oksidase.

\section{Densitas Kamba}

Tepung kacang turi berbunga putih yang dihasilkan pada penelitian ini berada pada kisaran nilai densitas kamba dari berbagai makanan bubuk yang umumnya antara 0.30-0.80 g/cm ${ }^{3}$ (Wirakartakusumah et al., 1992). Secara umum perlakuan pendahuluan perebusan 90 menit menghasilkan tepung dengan densitas kamba yang lebih tinggi, baik dengan kulit maupun tanpa kulit. MenurutNwosu (2010) serta Akaerue dan Onwuka (2010) nilai densitas kamba meningkat dengan adanya pemanasan.

Densitas kamba merupakan salah satu karakteristik fisik yang digunakan untuk merencanakan suatu gudang penyimpanan. Semakin besar densitas kamba suatu tepung akan semakin memperkecil ruangan penyimpanan atau pengemasan dan biaya transportasi Pangastuti (2012). Selain itu, densitas kamba juga menjadi pertimbangan dalam penggunaan jenis tepung (Indrasti, 2004). Bahan pangan dengan densitas kamba yang tinggi merupakan salah satu persyaratan dari makanan bayi (Marta, 2011).

\section{Kelarutan (Solubility)}

Penelitian ini menunjukkan adanya tren penurunan terhadap kelarutan tepung baik kacang turi berbunga putih dengan kulit maupun kupas kulit dengan perebusan 90 menit (F2 dan F5). Hal ini disebabkan pada saat perebusan 90 menit terjadi gelatinisasi pati dalam kacang turi berbunga putih dan setelah pengeringan dalam oven sehingga mengalami pati retrogradasi. Proses lanjutan setelah pati tergelatinisasi misalnya, pendinginan, pembekuan, pemanggangan atau penggorengan akan mengakibatkan terjadinya retrogradasi pati yang dapat mengubah struktur pati yang mengarah pada terbentuknya kristal baru yang tidak larut (Blackwell, 2013).

\section{KESIMPULAN}

1. Perlakuan perebusan 90 menit tanpa pengupasan kulit menghasilkan tepung dengan densitas kamba sama dengan control serta kadar abu, lemak, protein, asam fitat, $\mathrm{HCN}$, derajat putih, dan kelarutan yang lebih rendahdaripada kontrol.

2. Perlakuan perendaman 24 jam tanpa pengupasan kulit menghasilkan tepung dengan kadar lemak dan derajat putih sama dengan control serta kadar abu, 
protein, asam fitat, $\mathrm{HCN}$, densitas kamba, dan kelarutan yang lebih rendah daripada control.

3. Perlakuan pengupasan kulit menghasilkan tepung dengan kadar abu dan kelarutan sama dengan control, lemak, protein,derajat putih lebih tinggi daripadacontrol, serta kadar asam fitat, $\mathrm{HCN}$, dan densitas kamba lebih rendah daripada control.

4. Perlakuan perebusan 90 menit disertai pengupasan kulit menghasilkan tepung dengankadar lemak, protein, dan derajat putih lebih tinggi daripada control, serta kadar asam fitat, HCN, abu, densitas kamba dan kelarutan lebih rendah daripada control.

5. Perlakuan perendaman 24 jam disertai pengupasan kulit menghasilkan tepung dengan derajat putih sama dengan control, kadar lemak, protein, dan derajat putih lebih tinggi daripada control, serta kadar asam fitat, $\mathrm{HCN}$, abu, densitas kamba, dan kelarutan lebih rendah daripada control.

\section{DAFTAR PUSTAKA}

AOAC [Analysis of the Asociation of Official Agriculture Chemistry]. 1995. Analysis of the Asociation of Official Agriculture Chemistry. New York.

Agus, MurtidjoBambang. 2001. Pedoman Meramu Pakan Ikan. Penerbit Kanisius. Yogyakarta.

Alonso, R., A. Aguirre, dan F. Marzo. 2000. Effects of Extrusion and Traditional Processing Methods on Antinutrients and In Vitro Digestibility ofProtein and Starch in Faba and Kidney Bean. Food Chem., 68: 159-165. Dalam Ejigui, J., L. Savoie, J. M., dan T. Desrosiers. 2005. Influence of Traditional Processing Methods on the Nutritional Composition and Antinutritional Factors of Red Peanuts (Arachis hypogea) and Small Red Kidney Bean (Phaseolus vulgaris). Journal of Biological Sciences 5(5): 597605.

Angulo-Bejarano P, Verdugo-Montoya N, Cuevas-Rodríguez EO, Milán-Carrillo J,
Mora-Escobedo R, Garzón-Tiznado JA, Reyes-Moreno C. 2008. Tempeh flour from chickpea (Cicer arietinum L) Nutritional and physicochemical properties. Food Chem. 106:106-112

Apriyantono, A., D. Fardiaz, N.L. Puspitasari, dan S. Budianto. 1989. Petunjuk Analisa Pangan. PAU Pangan dan GiziInstitut Pertanian Bogor. Bogor.

Astawan, $\mathrm{M}$ dan Andreas LeomitroKasih.2008. Khasiat WarnaWarni Makanan. PT Gramedia Pustaka Utama. Jakarta.

Audu, S.S. dan M.O. Aremu. 2011. Effect of Processing on Chemical Composition of Red Kidney Bean (Phaseolus vulgaris L.) Flour. Pakistan Journal of Nutrition 10 (11): 1069-1075.

Akaerue BI, Onwuka GI. 2010. Evaluation of the yield, protein contentand functional properties of Mung bean (Vigna radiata L. Wilczek) protein isolates as affected by processing. Pak. J. Nutr. 9(8): 728-735.

Cahyo, Kartiko. 2012. Potensi Biji Saga Pohon (Adenanthera Pavonina, Linn) sebagai Bahan Baku Tempe, Sensori, Kualitas Gizi, Serat Pangan, dan Kapasitas Antioksidan. Teknologi Hail PertanianUniversitas Sebelas Maret. Surakarta.

Coimbra, MC, N.Jorge. 2011.Proximate composition of guariroba (Syagrus oleracea), jeriva (Syagrus romanzoffiana), and macauba (Acrocomia aculeata) palm fruits. Rod Research International 44(1):2139-2142.

Crean, D.E.C. dan D.R. Haisman. 1963. The Interaction Between Phytic Acid and Divalent Cations During the Cooking of Dried Peas. Journal of the Food Science of Food \& Agriculture 14:824-833. Dalam Khattab, R.Y. dan S.D. Arntfield. 2009. Nutritional Quality of Legume Seeds as Affected by Some Physical Treatments: Antinutritional Factors. LWT Food Science and Technology 42: 11131118. 
deMann, J.M. 1999. Principles of Food Chemistry. Springer. New York.

Ekawati. D. 1999. Pembuatan Cookies dari Tepung Kacang Merah (Phaseolus vulgaris L.) sebagai Makanan Pendamping ASI (MP-ASI). Skripsi Jurusan Gizi Masyarakat dan Sumberdaya Keluarga Fakultas PertanianInstitut Pertanian Bogor. Bogor.

El-Adawy, T.A. 2000. Nutritional Composition and Antinutritional Factors of Chickpeas (Cicer arietinumL.) Undergoing Different Cooking Method and Germination. Plant Foods for Human Nutrition 57: 83-97.

Feenstra, W.J. 1960. Biochemical Aspects of Seed Coat Colour Inheritance inPhaseolus vulgarisL. Meded Landbouwhogeschool Wangeningen60: 1-53. Dalam Anton, A.A., K.A. Ross, T. Beta, R.G. Fulcher, dan S.D. Arntfield. 2008. Effect of Pre-Dehulling Treatments on Some Nutritional and Physical Properties of Navy and Pinto Beans(Phaseolus vulgarisL.). LWT 41: 771-778.

Hilyatuzzahroh. 2006. Korelasi Kadar Tanin Pada Produk Teh Komersial dengan Aktivitasnya Sebagai Senyawa Antibakteri EPEC K1-1. SkripsiFMIPAIPB. Bogor.

Indrasti, F. 2004. Pemanfaatan Tepung Talas Belitung (Xanthosoma saginifolium) dalam Pembuatan Cookies. Skripsi Fakultas Teknologi Pertanian Institut Pertanian Bogor. Bogor.

Konietzny and Greiner.2006.Phytase for Food Aplication.Food Technol and Biotechnol. 44 (2): 125-140.

Mankotia, K. dan R. Modgil. 2003. Effect of Soaking, Sprouting, and Cooking on Physicochemical Properties of Moth Bean (Vigna aconitifolia). J. Hum. Ecol. 14(4): 297-299.

Marquardt, R.R., J.A. McKirdy, T. Ward and L.D. Campbell. 1975. Amino acid, hemagglutinin and trypsin inhibitor levels, and proximate analyses of faba beans (Vicia faba L. var. minor) and Faba bean fractions.Can. J. Anim. Sci. 55:421-429.

Marta, H. 2011. Sifat Fungsional dan Reologi Tepung Jagung Nikstamal derta Aplikasinya pada Pembuatan Makanan Pendamping ASI. Sekolah Pascasarjana Institut Pertanian Bogor. Bogor

Mardiah E. 1996. Penentuan aktivitas dan inhibisi enzim polifenol oksidase dari apel (Pyrus malus Linn.).Jurnal Kimia Andalas 2(2):16-18

Mubarak A.E. 2005. Nutritional Composition and Antinutritional Factors of Mung Bean Seeds (Phaseolus Aereus) as Affected by Some Home Traditional Processes. Food Chem. 89: 489-495.

Mohammed, R., E.A. Abou-Arab, A.Y. Gibriel, N.M.H. Rasmy, F.M. Abu Salem. 2011. Effect of Legume Processing Treatments Individually or In Combination on Their Phytic Acid Content. African Journal of Food Science and Technology 2(2) : 036-046.

Nurhidayat., Padaga, Masdiana C., dan Suhartini, Sri. 2006. Mikrobiologi Industri. Andi. Yogyakarta.

Nwosu, J.N. 2010. The Effects of Processing on the Functional Properties of Oze(Bosquela angolensis)Seeds.Pakistan Journal of Nutrition 9 (8): 781-786.

Nzewi, D. dan A.C.C. Egbuonu. 2011. Effect of Boiling and Roasting on the Proximate Properties of Asparagus Bean (Vigna sesquipedalis). African Journal of Biotechnology Vol. 10(54): 1123911244.

Pangastuti, Hesti. 2012. Karakterisasi Sifat Fisik Dan Kimia Tepung Kacang Merah (Phaseolus Vulgaris L.) dengan Beberapa Perlakuan Pendahuluan. Skripsi Ilmu dan Teknologi Pangan Universitas Sebelas Maret. Surakarta.

Paramita, Dian Sri. 2008. Pengaruh Teknik Pemanasan terhadap Kadar Asam Fitat dan antioksidan Koro Benguk (Mucuna pruriens), Koro Glinding (Phaseolus 
bunatus), dan Koro Pedang (Canavalia ensivormis). SkripsiFakultas Pertanian Universitas Sebelas Maret,. Surakarta.

Pinasthi, W. 2011. Pengaruh modifikasi Heat Moisture Treatment (HMT) dengan radiasi microwave terhadap karakteristik fisikokimia dan fungsional tapioka dan maizena.Skripsi Fakultas Teknologi Pertanian Institut Pertanian Bogor. Bogor.

Setyono, A. 1988. Perilaku Asam Fitat dalam Pengolahan Kedelai. UGM Press. Yogyakarta.

Siregar, Nurdiansyah. 2009. Pengaruh Lama Perendaman Daun Teh terhadap Kadar Tanin. Karya Ilmiah Universitas Sumatera Utara. Medan.

Sutikno, AI. 1999. Pengolahan Biji Turi (Sesbania grandiflora) untuk mengurangi senyawa Anti Nutrisi. Buletin IlmuTernak9 (1): 7-10.

Widowati, S. 2009. Tepung Aneka Umbi: Sebuah Solusi Ketahanan Pangan. Sinar Tani Edisi No. 3302 .

Wheeler, E.L., Ferrel, R.E. 1971. A method for Phytic Acid Determination in Wheat and Wheat Fractions. AACC Journal 48:312-320.

Wirakartakusumah M.A., Abdullah K., Syarif A.M. 1992. Sifat Fisik Pangan. Pusat Antar Universitas Pangan dan Gizi IPB. Bogor.

Winarno, F.G. 2004. Kimia Pangan Gizi. Gramedia Pustaka Utama. Jakarta. 